\title{
Non-mega sport events' social impacts: A sensemaking approach of local governments' perceptions and strategies.
}

\author{
Mathieu Djaballah*, Christopher Hautbois*, \& Michel Desbordes* \\ *1 - CIAMS, Univ. Paris-Sud, Université Paris-Saclay, 91405 Orsay Cedex, France \\ 2 - CIAMS, Université d'Orléans, 45067, Orléans, France
}

\begin{abstract}
This article explores how local governments make sense of non-mega sport events' social impacts. Semi-structured interviews were conducted with local sports officials from 25 medium-sized French cities. Based on the theoretical framework of strategic sensemaking, we analyze how they collect and interpret information concerning these impacts, and how these interpretations influence their hosting strategies. Results show that while they perceive more positive than negative impacts, they are nonetheless proportionally more involved in the management of negative impacts. Two main gaps are identified in their sensemaking process. One gap relates to the understandability of positive impacts, and the other relates to their controllability. Four ways of managing these impacts are presented with supporting evidence, namely organizer relationship management, direct management, community mobilization, and partnerships with local corporations. Furthermore, several suggestions are made to increase the understandability and controllability of social outcomes.
\end{abstract}

KEYWORDS: Sport events; Social impacts; Sensemaking; Stakeholder view; Local governments. 


\section{Introduction.}

Although sporting events are of a short duration, they can generate various short or long term impacts (Preuss \& Solberg, 2006; Richie, 1984). Most attention on this subject has been given to mega sport events like the Olympic Games or the Fédération Internationale de Football Association (Fifa) World Cup, which fall into the 'Type A' category of Gratton and Taylor's (2000) typology of events, namely 'irregular, one-off, major international spectator events generating significant economic activity and media interest' (Gratton \& Taylor, 2000, p.190). As these events are largely used to develop tourism (Briedenhann, 2011; Xing \& Chalip, 2006), provide new business opportunities (Spilling, 1996) or stimulate job creation (Roche, 1994), the focus of research has primarily been on their economic impacts. From an economic perspective, the authors point that these impacts are actually limited, at least for local communities (Preuss, 2004). At the same time, while their non-economic outcomes had been 'relegated to the realm of interesting anecdotes' (Chalip, 2006, p.111), they are now the subject of growing interest (Carey, Mason \& Misener, 2011; Hiller, 2000). Authors have notably begun to explore intangible social impacts that could help refine broader cost-benefit analyses (Wicker, Hallman, Breuer \& Feiler, 2012).

By contrast, non-mega events, which can be broadly defined as 'smaller in size, scale, scope and reach than their mega counterparts' (Taks, 2013, p124) have received less scrutiny, both on the economic and social levels (at the exception of several contributions presented in the next sections). Yet, these events may provide, at least in some respects, better and more sustainable social outcomes for local communities. Regarding tangible outcomes, the lower costs of their hosting may allow a better redistribution of public funding (Taks, 2013). Regarding intangible outcomes, these events may generate stronger feelings of community belonging (O’Brien, 2007) and empowerment (Taks, Kesenne, Chalip \& Green, 2011). Furthermore, such outcomes may be more widespread, since non-mega events far outnumber mega events on an aggregate level and do not solely concern bigger cities (Taks, 2013). As there are large varieties of non-mega sport events, this study adopts a relatively broad scope, considering Gratton and Taylor's (2000) 'Type C' and 'Type D' categories ${ }^{1}$, namely major international or national events, generating limited economic activity, that are either one-off or part of a regular cycle. Both categories are included as they fit the reality of most mediumsized cities. However, to ensure consistency with our literature review, we exclude participatory events whose social impacts may be different in their very nature.

Therefore, this study explores the social impacts of non-mega sport events. More particularly, these impacts are examined through the lens of local governments. In this sense, we follow the recommendation of Misener and Mason (2010) that more attention should be paid to the ways in which organizations deal with these impacts. Indeed, local governments have a pivotal role in sporting events' social impacts. On the one hand, they provide sporting events with essential resources (financial support, access to sport facilities), which give them

\footnotetext{
${ }^{1}$ Type B events are defined as 'Major spectator events generating significant economic activity, media interest and part of an annual cycle of sport events' (Gratton \& Taylor, 2000, 190).
} 
important leverage in the decision-making process. On the other hand, their function is to represent the interests of the local community. As a consequence, not only should they be concerned with these impacts, but they also are in a position to influence them. Hence, drawing on the strategic sensemaking approach (Gioia \& Chittipeddi, 1991; Thomas, Clark \& Gioia, 1993), this study aims at better understanding how local governments make sense of sporting events' social impacts and how their perceptions of such impacts influence their hosting strategies.

The paper is structured as follows. First, we present the theoretical framework of strategic sensemaking. Then, we describe the possible social impacts associated with nonmega sport events, and envision them in a sensemaking perspective in order to delineate the objectives of this study. In the fourth section, we describe the methods, including the research design, data collection, and data analysis. Finally, we present our findings and discuss them in light of both sensemaking and sport management literatures.

\section{Strategic sensemaking.}

The original notion of sensemaking refers to the process by which people give meaning to experience (Weick, 1979). Applied to the field of organizational behavior by Karl E. Weick (1979; 1995), it introduced cognitive dimensions into the management literature and contributed to the advancement of organizational psychology. Sensemaking draws upon the interpretive approach, which lies on the assumption that 'human understanding and action are based on the interpretation of information and events by the people experiencing them' (Gioia \& Chittipeddi, 1991, p.435). Accordingly, given the complexity of the real world, the sensemaking process aims at extracting information or 'cues' (Weick, 1979) from the environment and interpreting them in order 'to create an account of what is going on' (Maitlis \& Sonenshein, 2010, p.553). In organizational studies, sensemaking occurs when managers are faced with uncertain or ambiguous environments (Weick, 1995). In an uncertain environment, managers are unable to provide any interpretation of a situation. In an ambiguous environment, managers are confused with too many interpretations of the situation.

Weick's $(1979 ; 1995)$ sensemaking theory is essentially retrospective, in the sense it is mainly based on past experience to make sense of the present (Gioia \& Mehra, 1996). However, the sensemaking literature developed towards strategic sensemaking (Gioia \& Chittipeddi, 1991; Thomas et al., 1993), a prospective form of sensemaking defined as 'an attempt to structure the future by imagining some desirable (albeit ill-defined) state [...] one that we conceptualize in the present but realize in the future' (Gioia \& Mehra, 1996, p.1229). Strategic sensemaking explores 'the link between how [...] organizations make sense of information and how they act to influence organizational outcomes' (Thomas et al., 1993). It entails three key processes - scanning, interpretation, and action (Gioia \& Chittipeddi, 1991). 
The scanning phase refers to the gathering of information in the environment. Although scanning is a continuous activity of organizations (Maitlis \& Sonenshein, 2010), it may intensify when a change occurs in the environment, putting the organization in front of new issues. This intensification of scanning acts as a trigger for the strategic sensemaking process (Dutton \& Jackson, 1987). In most cases, the difficulty comes less from the accessibility of information than from the need to select it, as managers often have access to more information than they can use (Thomas et al., 1993). It is also important to note the active and subjective nature of scanning: for managers, the central issue is to know what they are looking to find. As a result, some information may not be selected as relevant and hence left out of the sensemaking process. Thomas et al. (1993) noted that scanning can be fed by two types of information: information relating to organizations' external environment which enables them to identify issues that might affect them and information relating to an organizations' internal environment which enables them to identify elements upon which they may rely. This scanning activity therefore enables the following steps of the sensemaking process by feeding the interpretive structure which activates strategic actions.

The interpretation phase aims at connecting the selected cues to a structure for interpreting. Gioia (1986) defines interpretation as the development or applications of ways of comprehending the meaning of information. The interpretive structure sorts the information into categories in order to facilitate their understandability (Dutton \& Jackson, 1987). Thomas and McDaniel (1990) empirically demonstrated that most organizations' interpretation systems were constituted of two dimensions: whether the issue is positive or negative, and whether it is controllable or uncontrollable. At the organizational level, well-known types of interpretive structures include the SWOT matrix, which distinguishes between internal (strengths and weaknesses) and external (opportunities and threats) information. However, interpretive structures can also exist at an individual and cognitive level (Thomas et al., 1993). Furthermore, this interpretation phase is also subjective. The same information may be labelled as positive or negative, and as controllable or uncontrollable, depending on the organization.

The third stage (action) refers to the organizational responses resulting from the accounts generated by the two first stages. A central premise of sensemaking is that the way an organization interprets an issue heavily influences its responses (Thomas et al., 1993). Dutton and Jackson (1987) contend that the interpretive labels defined by managers can influence the degree of involvement of the organization in an issue, as well as the resources invested. More particularly, the perception of an issue as negative may narrow the number of alternatives for action, while positive perceptions may trigger more innovative forms of organizational response, through a broader range of perceived opportunities. According to Thomas et al. (1993), the link between interpretations and action can only be activated when the issue is perceived as controllable, regardless of the positive-negative dimension.

Hence, strategic sensemaking is a process by which managers try to understand the context and environment of their organization in order to make better informed organizational decisions, and ultimately improve organizational performance. We suggest that this approach 
is of great interest to study sporting events' social impacts. Indeed, the sensemaking approach has gained growing attention, notably in social responsibility literature, because it provides a better understanding of how an organization and its stakeholders deal with the ambiguity of social issues by searching for their meaning (Angus-Leppan, Metcalf \& Benn, 2010). This approach may thus be appropriate to describe how local governments interpret non-mega sport events' social impacts, and how these interpretations lead to specific actions. In what follows, we approach the topic of sport events' social impacts and envision more particularly these impacts in the context of non-mega events.

\section{Non-mega sport events' social impacts.}

As pointed out by several authors (Balduck, Maes \& Buelens, 2011; Ohmann, Jones, \& Wilkes, 2006), there is no specific definition of sporting events' social impacts. Balduck et al. (2011) refer to a definition of tourism impacts, namely 'changes in the collective and individual value systems, behavior patterns, community structures, lifestyle and quality of life' (adapted from Hall, 1992, p.67). Lee, Cornwell, and Babiak (2012) recently developed a 'Social Impact of Sport Scale' based on five dimensions (social capital, collective identities, health literacy, well-being and human capital), which is applicable to a variety of sport and exercise initiatives but may miss some specific characteristics of sport events.

What's more, the various classifications of sporting events' impacts proposed in the literature (Brown \& Massey, 2001; Preuss \& Solberg, 2006; Ritchie, 1984) do not integrate all social impacts within the same category, as some distinguish socio-cultural impacts from other impacts which may also contain social dimensions (psychological, physical, political). In this study social impacts do not only refer to Ritchie's (1984) or Preuss and Solberg's (2006) socio-cultural category, but include other impacts which may also affect local residents' quality of life, as pointed by Taks (2013). As a result, although focusing on the local community, we base our literature review on an extended definition of social impacts, including social capital, well-being, collective identities, sport participation, urban regeneration and human capital. These impacts have the property of generating positive or negative social outcomes that may persist after the event (Preuss, 2007).

\subsection{Social capital.}

Lee et al. (2012, p.27) define social capital - basing on Coleman's (1994) definition - as 'social relationships and conditions including trustworthy and diverse networks, social proactivity and participation in community conducive to cooperation for mutual success in society'. Misener and Mason (2006) argue that sporting events may constitute an important source of social capital for various stakeholders, since they help them build community networks through multi-partnership opportunities. Such partnerships can be oriented towards the improvement of local community's quality of life, as illustrated by the 'Wired-up Communities' program, a partnership between the UK government and internet service 
providers, intended to give internet access to low income local residents during the 2002 Commonwealth Games in Manchester. However, as pointed by Smith (2009), social capital should less be considered as an outcome than as a means to ensure social benefits for specific groups. Consistent with this view, Misener and Mason $(2008 ; 2009 ; 2010)$ suggest that local communities should be put at the center of the event's strategy. Social capital includes dimensions such as local citizenship, neighborhood connections or intercultural dialogue (Kellett, Hede, \& Chalip, 2008 ; Misener \& Mason, 2009). According to Taks (2013), while mega events often instigate a vertical social capital which can lead to inequalities between local elites and the local community (Whitson \& Horne, 2006), non-mega events may encourage a horizontal social capital and create stronger networks within the community, mainly due to a more appropriate level of bounding and local ownership. As a consequence, non-mega sport events could better serve civic matters, as illustrated by Ruhanen and Whitford (2011) who showed how an indigenous sports festival in Australia provides a momentum for the reconciliation with the aboriginal community.

There are other dimensions, namely well-being, collective identities, sport participation and human capital, which may be part of a broader conception of social capital, but which we envision as separates outcomes due to the specific interest they have generated in the literature.

\subsection{Well-being and collective identities.}

The definition of well-being set forth by Lee et al. (2012, p.27), namely 'harmonious life quality in both psychological and economic aspects for human function and development', is quite vast and includes non-strictly socio-cultural impacts (notably the benefits from sport participation) which will be evoked later. Nevertheless, the literature linking sport events to well-being is extensive, albeit mostly focused on mega events. In sum, mega events seem to generate a 'feelgood' effect that may be associated with 'the enjoyment of attending events, of being involved as a volunteer organizer, of the proximity of the events even if one does not attend, cultural showcases, and national pride' (Kavetsos and Szymanski, 2010, p.159). Well-being may however be tempered by various negative impacts, such as pedestrian and traffic congestion, noise, violence, vandalism, urban degradation and other anti-social behaviors that Fischer, Hatch and Paix (1986) grouped under the term 'hoon effect' (Fredline \& Faulkner, 2002).

Furthermore, several studies questioned whether national or city pride was a recurring outcome relating to well-being (Walker, Heere, Gibson, Thapa, Geldenhuys \& Coetzee, 2012). Kavetsos and Szymanski (2010), through a study of twelve European countries, point that the feelgood effect is essentially associated with hosting the event. National or local team success would rather constitute dimensions of 'collective identities', which refer to 'the sense of belonging to a social group or community reflecting self-categorization with positive attitude and important self-concept in a social context' (Lee et al., 2012, p.27). Sport events 
have been found to foster collective identities in a variety of ways. According to Chalip (2006), they have the ability to create a sense of community (called communitas) among people who are present. Interestingly, some studies identify collective identities effects in non-mega events. For example, McGabe (2006) showed how a traditional football festival in UK contributes to preserving some features of the multi-secular community's identity. However, collective identities may lead to negative social outcomes, especially when they are defined in opposition to other identities, thus eliciting feelings of ultra-nationalism or stigmatization (Buffington, 2012).

\subsection{Sport participation}

The rationale linking the hosting of sport events to sport participation is that these events 'encourage [the] population to become more physically active' (Frawley \& Cush, 2011, p.65). However, this outcome is not clearly demonstrated. While most studies conclude that no, little, or only short-time effects occur (Weed, Coren \& Fiore, 2009), some others point to more sustainable outcomes (Frawley \& Cush, 2011). Like for other social outcomes, the authors insist on the need for implementing coherent sport development programs to accompany the host community towards sport activities prior to and after the events (Weed, Coren \& Fiore, 2009). As far as they are concerned, studies on the impact of non-mega events on sport participation are scarce. Nevertheless, Girginov and Hills (2008) suggest that their ubiquitous character may be taken into account to foster sport participation on an aggregate level.

\subsection{Human capital.}

Human capital can be defined as 'the attributes of individuals in terms of knowledge, skills, competencies, and attitudes conducive to personal development and societal wellbeing' (Lee et al. 2012, p.27). In this regard sporting events, notably through the volunteer opportunities they offer, encourage social interactions, knowledge exchange, leadership skills, mutual assistance and capacity building (Nicholson \& Hoye, 2008). In disadvantaged areas more specifically, the strengthening of human capital can favor a form of social justice since the skills acquired may improve people's employability (Jones \& Strokes, 2003). However, while most mega-events launch volunteer programs, it remains difficult to gauge their actual impact on human capital (Zhuang, \& Girginov, 2012). From a local community perspective and according to Taks (2013), mega events' volunteer programs may not be well suited to foster human capital in that they involve volunteers from other regions or countries and offer mainly unfulfilling tasks that may not develop marketable capacities. On the opposite, nonmega events present the benefits of addressing primarily local residents, and entrusting them with higher responsibilities.

\subsection{Urban regeneration.}


Concerning urban regeneration, mega and non-mega events seem hardly comparable, as the formers can engender drastic transformations of cities (Hiller, 2000) while the latters are usually far less demanding in terms of infrastructures (Taks, 2013). Acknowledging that does however not mean that urban regeneration outcomes are necessarily better for mega events. Indeed, the world class facilities needed to host them do not always correlate with the present and future needs of the host community (Cashman, 2006). What's more, these events can have other negative urban consequences, like housing price booms or even eviction of poor populations (Jennings, 2000). Here again, the social purpose of such urban remodeling requires specific attention and should not be considered as a mere bonus (Misener \& Mason, 2009). As for non-mega events, Taks, Chalip, Green and Misener (2012) identified another approach, potentially more beneficial, where events are used (and hence specifically picked) to achieve previously planned construction or upgrading of sport facilities, rather than the opposite. Hence, beyond gross comparison between mega and non-mega events' urban legacies, one could argue that smaller cities' may make a more rational use of non-mega sport events than bigger cities do with mega events.

Obviously, we do not claim to exhaustively cover all possible social impacts of nonmega sport events. We essentially focused on middle-to long term impacts, which may contribute to their legacy (Preuss, 2007). In the following sections, we draw from the strategic sensemaking approach in order to envision these impacts through the perceptions of local governments.

\section{Local governments' strategic sensemaking process of non-mega sport events' social impacts.}

As mentioned earlier, local governments are in a peculiar position regarding the management of sporting events' impacts, since their role is to serve as an intermediary between event organizers and the local community. Hence, the nature of their task is threefolded: they have to understand the various social impacts which sporting events may trigger, the expectations of their local community, and they have to convey those expectations to the organizers in order to enable positive and minimize negative impacts. Such tasks can be described as a strategic sensemaking process in the sense that involves the reciprocal interaction of information seeking, meaning ascription, and organizational response (Thomas et al., 1993).

Furthermore, from a sensemaking perspective, sport events' social impacts constitute an ambiguous issue, namely an issue that can generate contradictory perceptions. This ambiguity stems from the fact that their positive and negative impacts seem not to be addressed at the same level. More precisely, there seems to be a dichotomy between a vision of sporting events as a vector for positive impacts through social leveraging (Beesley \& Chalip 2011; Chalip, 2006; Kellett \& Chalip, 2008) and another vision that focuses on their negative impacts, notably through risk management (George \& Swart, 2012; Leopkey \& Parent, 2009). While 
the management of positive impacts is not contradictory, but complementary with the management of negative impacts, each one derives from a different set of perceptions. Hence, we can wonder if in some instances, one set does not prevail over the other, leading alternatively the sensemaking process of local governments towards the generation of positive impacts or the reduction of negative impacts.

In the next paragraphs, we frame our research questions following to the three stages of scanning, interpretation and action in order to analyze local governments' strategic sensemaking process.

\section{SCANNING}

Regarding the scanning phase, while sporting events' economic impacts often lead to ex ante or ex post assessments which provide useful information, such tools seem much less widespread as regards their social impacts (Horne \& Manzenreiter, 2006). It is therefore questionable to what extent local governments enter a scanning activity. Hence our research will address both the process and the content of scanning with the following questions: (1) how local governments gather information relating to sporting events' social impacts and (2) what external and internal information do they integrate into their scanning process?

\section{INTERPRETATION}

Regarding the interpretation phase, as most interpretive structures are constituted of the positive-negative and the controllable-uncontrollable dimensions (Thomas \& McDaniel, 1990), our questions are (1) what are the perceived positive and negative impacts of non-mega sporting events for local governments and (2) to what extent do they consider these impacts controllable? We feel these are relevant questions as sporting events' social impacts can lead to positive or negative interpretations (Balduck et al., 2011). What's more, the fact that social impacts are often overlooked (Chalip, 2006) may stem from their lack of controllability.

\section{$A C T I O N$}

Regarding the action phase, local governments have multiple ways to manage sporting events' social impacts. They may exert pressure on sporting events' organizers through financial agreements; they may deal directly with some impacts or they may partner with other actors in the local community. As the strategic sensemaking literature points that organizational responses are influenced by the scanning and interpreting activities (Thomas et al., 1993), our research question is what actions do local governments take around sport events' social impacts based on their sensemaking process?

Therefore, the objectives of this study are to examine how local authorities make sense of non-mega sport events' social impacts (scanning and interpretation) and how this sense influence the strategies implemented to manage these impacts (action).

\section{Methods.}

\subsection{Data collection.}


In-depth interviews were conducted between March 2012 and April 2013, with local sports officials from 25 medium-sized French cities. Table 1 indicates the breakdown of interviewees. As larger and smaller cities can also host non-mega events, we decided not to include them in our sample. Regarding large cities of more than 500000 inhabitants, the number of non-mega events they host seems too great to allow for a detailed sensemaking process of each event by sport officials who already deal with bigger events. Regarding small cities of less than 50000 inhabitants, the lack of human and financial resources allocated to the hosting of sport events may reduce the possibilities for managing social impacts. The interviews ranged from 45 to 75 minutes. They were conducted by the lead author, some in person and others via telephone. Respondents were city officials in charge of sporting events. In some cities, the head official in charge of sporting events was the Director of sports. They were recruited because of their key position: firstly, they directly participate in the formulation of the municipal sport policy, which is part of the city's broader political project. Secondly, they are in direct contact with event organizers, therefore in a position to implement this policy with respect to sport events. Thirdly, contrary to local politicians, local officials are not elected. The fact that they keep their position regardless of election outcomes makes them less subjected to a bias towards positive perceptions. Indeed, some of them did not hesitate to be quite critical regarding events' outcomes.

Prior to the interview, respondents were asked to list the main events that had been hosted in the city within the last four years. However, all events mentioned were hosted within the last three years apart from one. As accuracy of retrospective accounts can be questioned, there seems to be agreement that data can still be valid if questions do not get into too great a level of detail (Miller et al., 1997). What's more, it is to be noticed that events mentioned constitute major events for these cities and are particularly memorable for respondents. Nevertheless, a list of key issues to be discussed was provided in advance of interviews in order to decrease memory lapses. In agreement with respondents, we selected only events where the public funding amount ranged from 100000 to 500000 euros, assuming that cities' objectives may vary depending on the financial resources they provide. As mentioned earlier, we decided to keep both one-off and recurrent sporting events, because the perceptions of local governments regarding spectator sport events' social impacts may spread to both of these types.

Interviews started with questions pertaining to the broad objectives of the city in hosting the selected events. Then, we asked them to express their perceptions about the positive and negative social impacts these events may have on the local community. The precise meaning of the various impacts was left open in order to allow for participants' own understanding and definitions. Respondents were continually encouraged to provide examples of the impacts they mentioned, and to describe their role in the realization of these impacts.

We also asked complementary questions relating to the scanning activity (for example 'do you collect some information relating to social impacts prior to or after the events? What type of information? How do you collect it?') and to the actions implemented by the city in order to manage these impacts (for example 'how do you communicate your expectations to organizers, are there specific criteria relating to social aspects in partnership agreements?'). 
The interviews were audio recorded and transcribed verbatim. They were reviewed by the authors and sent to the participants to ensure accuracy of the data. Secondary data, including 41 documents (partnership agreements, conventions of objectives, general missions of the city sports department) were also collected in order to provide background information and illustrate the findings. 
Table 1. Breakdown of interview respondents

\begin{tabular}{|c|c|c|c|c|}
\hline \multicolumn{2}{|c|}{ City } & Population & Hosted sport events & Position \\
\hline $\begin{array}{l}\text { From } 50000 \text { to } \\
100000 \\
\text { inhabitants (9) }\end{array}$ & $\begin{array}{l}\text { Le Touquet } \\
\text { Saint-Quentin } \\
\text { Chambéry } \\
\text { Brive } \\
\text { Ivry-sur-Seine } \\
\text { Soorts-Hossegor } \\
\text { Tourcoing } \\
\text { Dunkerque } \\
\text { Roubaix }\end{array}$ & $\begin{array}{l}51021\left(\mathrm{cc}^{*}\right) \\
55978 \\
57342\left(\mathrm{cc}^{*}\right) \\
80253\left(\mathrm{cc}^{*}\right) \\
89985 \\
91345\left(\mathrm{cc}^{*}\right) \\
91923 \\
92005 \\
94713\end{array}$ & $\begin{array}{c}\text { Enduropale du Touquet (motocross) (yearly) } \\
\text { Tour de Picardie (cycling) (yearly) } \\
2012 \text { FIS Alpine Ski World Cup } \\
2009 \text { World Junior Rowing Championships } \\
\text { Marrane Challenge (Handball) (yearly) } \\
\text { Quicksilver Pro France (surfing) (yearly) } \\
\text { U23 International Basketball Tournament (yearly) } \\
2012 \text { National Swimming championships } \\
\text { Paris-Roubaix (cycling) (yearly) }\end{array}$ & - 9 Directors of sports \\
\hline $\begin{array}{l}\text { From } 100000 \text { to } \\
200000 \\
\text { inhabitants }(8)\end{array}$ & $\begin{array}{l}\text { Saint Denis } \\
\text { Caen } \\
\text { Limoges } \\
\text { Brest } \\
\text { Angers } \\
\text { Orléans } \\
\text { Le Havre } \\
\text { Reims }\end{array}$ & $\begin{array}{l}106785 \\
108954 \\
139150 \\
141303 \\
147571 \\
153490 \\
175497 \\
179992\end{array}$ & $\begin{array}{c}\text { Six nations Tournament (rugby) (yearly) } \\
\text { International Jumping of Caen (Equestrianism) (yearly) } \\
\text { Fed Cup (2009, 2013) } \\
\text { Krys Ocean Race (yearly) } \\
\text { 2012 National Athletics Championships } \\
\text { 2011 Fencing World Cup/ 2010 European Judo Cup } \\
\text { Transat Jacques Vabre (sailing) (every } 3 \text { years) } \\
\text { 2013 Fise Xpérience Séries }\end{array}$ & $\begin{array}{c}\text { - } 5 \text { Directors of sports } \\
\text { - } 3 \text { Officials in charge of sport } \\
\text { events }\end{array}$ \\
\hline $\begin{array}{l}\text { From } 200000 \text { to } \\
350000 \\
\text { inhabitants }(8)\end{array}$ & $\begin{array}{l}\text { Rennes } \\
\text { Metz } \\
\text { Lille } \\
\text { Bordeaux } \\
\text { Poitiers } \\
\text { Montpellier } \\
\text { Strasbourg } \\
\text { Nice }\end{array}$ & $\begin{array}{l}206604 \\
225157 \\
226827 \\
235891 \\
249196 \\
255080 \\
276401 \\
343 \quad 304\end{array}$ & $\begin{array}{c}2013 \text { National Swimming championships } \\
\text { ATP } 250 \text { Moselle Open (yearly) } \\
2013 \text { Euro-Basket Women } \\
2012 \text { World BMX Championship } \\
\text { Tour du Poitou-Charente (cycling) (yearly) } \\
\text { FISE (action sports) (yearly) } \\
\text { Open ATP de Strasbourg (yearly) } \\
\text { Open ATP NCA/ Meeting Nikaïa (yearly) }\end{array}$ & $\begin{array}{c}\text { - } 4 \text { Directors of sports } \\
\text { - } 4 \text { Officials in charge of sport } \\
\text { events }\end{array}$ \\
\hline
\end{tabular}

*Community of communes. 


\subsection{Data analysis.}

Interview transcripts were analyzed using QSR Nvivo10, an analytical software designed for managing large amounts of qualitative data. Following the recommendations of Bandara (2006), we first created two sets of primary nodes, one referring to the sport events' social impacts defined in our literature review, the other to the three stages of the sensemaking process (scanning, interpretation, and action). The data were coded at these two sets of nodes in order to cross social impacts and strategic sensemaking dimensions. Regarding social impacts, a further examination of data led to the creation of 'sub nodes' as some dimensions emerged which refined higher order nodes. For example, within the node 'social capital', besides sub-dimensions that had already been identified in the literature review - like 'neighborhood connections' or 'local citizenship' - we created specific nodes such as 'benefits for disadvantaged groups' or 'inclusion of disabled persons'. Regarding strategic sensemaking, each phase was subjected to a specific coding structure. Within the 'scanning' node, we coded the data based on the source and the nature of information gathered. Within the 'interpretation' node, we distinguished between positive and negative perceptions. Then, a coding round was performed in order to analyze the controllability of these impacts. We thereby distinguished between 'supposed impacts' (not supported with clear examples), 'observed impacts' (supported with clear examples but not managed by local governments), and 'controlled impacts' (impacts for which the local governments were directly involved). Within the 'action' node, we coded the data along four types of local governments' involvement (organizers relationship management, direct management, community mobilization and partnerships with local corporations). Only 'controlled impacts' were coded at 'action', as other impacts were not subjected to any involvement of local governments.

During this phase, the researchers read through transcripts independently. Isolated quotations were then compared and discussed. To enhance trustworthiness, all new constructs were discussed between the authors. When a new node was added, data that had already been coded were examined a second time and recoded at this new node when appropriate. The analysis was based on the relevance and frequency of quotations. By counting the number of respondents (sources) and quotations (references), we determined local governments' perspectives regarding sport events' social impacts.

\section{Results.}

Overall, most respondents expressed the need to ensure the social utility of sport events in a more genuine manner. In this sense, they point to a general transition from older hosting policies, where events were only intended to entertain the local community (in addition to bringing economic outcomes for some of them). However, if attention is given to the needs of local community groups, it appears that social impacts drive heterogeneous sensemaking 
processes. More particularly, although local governments identify both positive and negative social impacts, they are proportionally more involved in the management of negative impacts.

\subsection{Scanning.}

In most cities of our sample, the scanning activity of local governments about sport events' social impacts seems limited. Indeed, if respondents mention both external and internal sources of information, external information is mentioned by fewer respondents than internal information.

\section{External information.}

Regarding external information, 14 local governments report that they usually consult some local community groups prior to events. Nearby residents is the main group providing information to local governments (10 respondents), notably during meetings held prior to events. An interesting point is that the information gathered from them is often related to negative impacts, as illustrated by this quote:

'People were invited to express their concerns. Questions raised included how they would be able to get to their homes, where they would be able to park their cars, would there be an additional garbage service to avoid piles of beer bottles...' (Reims).

Another source of external information from residents, much rarer in our sample, is constituted by surveys. Two respondents (Rennes and Lille) passed questionnaires to evaluate their reactions to the hosting of some events. These questionnaires, though sent after previous events, were used in the scanning phase for next events. Each of them concluded to mostly positive opinions, which may appear inconsistent with the prior mentioned information gathered with nearby residents. However this can be explained by the low number of questions and their scope, since they only addressed broad aspects relating to city image, as exampled by this question:

In your opinion, does the Euro Basket Women contribute to the reputation of Lille? (Lille).

Local clubs are also mentioned as sources of external information (7 respondents). However, only clubs taking part to events' organizing committees are consulted. What's more, for most respondents, social impacts do not constitute the primary topic of these meetings. Rather, local governments are simply informed of some social actions without necessarily seeking clarifications, as indicated by the following example:

'Honestly, with the club the main issue was the financing of a shuttle service to get competitors from their hotels to the swimming pool, as we were originally 
not supposed to pay for that [...]. Then they told us about [giving free swimming lessons for children], we found that it was a nice idea' (Rennes).

\section{Internal information.}

By contrast, nearly all local governments (23 respondents) feed their scanning process with internal information, namely information that comes from their broader municipal sport policy. Indeed in most cities, the sport policy covers a range of social issues, as evoked by this respondent:

'We consider that sport is not only a matter of sport but contributes to other priority areas, social integration, women participation, inclusion of disabled persons. So we increasingly enter sporting events through these angles, in order to develop animations that come as a continuity of our sports policies' (Angers).

The fact that the social issues addressed by sport policies constitute the main source of information used by local governments to make sense of sport events' social impacts suggests that their scanning process follows a very particular pattern. A first point is that very few information is actually linked to social impacts of events strictly speaking, and even less on their positive impacts. Therefore, it can be assumed that this type of scanning does not allow for the understandability of such impacts.

Above all, a main idiosyncrasy is that this form of scanning may lead local governments to engage in a somewhat reverse sensemaking process, making sense of social impacts not by basing on the potential of the events, but rather by trying to extend broader social policies to their hosting strategies. Such a process may not leave room for the variety of events, thus restricting the scope of strategies as every event would be harnessed to the sport policy in a standard fashion.

In this regard, we nonetheless found some differences between one-off and recurrent events. Indeed, while one-off events raise unusual organizational constraints which primarily focus the attention of local governments, the better mastering of recurrent events' constraints sometimes leads hosting strategies towards a form of continual improvement, thus allowing for a deeper scanning activity on social impacts:

In the early years, we simply invited schools to watch the event. They came, watched some matches and it was over. But after three years, as routines were settled and as there was continuity in our relationship with the organizers, we capitalized on this experience to increase in quality. So we began to think about more matured projects for schools' (Metz).

However, even in the case of recurrent events, we did not find any example of the gathering of evaluative information such as social impact assessments. In the following section, we address local governments' interpretation of non-mega sport events' social impacts and envision the consequences of the scanning phase on their interpretive structure. 


\subsection{Interpretation.}

\section{Positive and negative perceptions.}

Overall, references to positive impacts (73\%) largely outnumber references to negative impacts (27\%, see Table 2). Social capital is the most mentioned positive impact $(28,9 \%)$. Respondents notably refer to two specific groups, namely youth and disadvantaged groups (quotation 1). 22 interviewees point out that events provide activities or educational programs like the invitation of 800 children to the opening parade of the 2012 National Athletics Championships in Angers. 18 interviewees feel that events tend to be more inclusive of disadvantaged-groups. Conversely, events which do not take these groups into account are perceived in a negative way (quotation 3 ).

Social capital includes positive references to local citizenship (notably donations for local causes, see quotation 2) neighborhood connections and intercultural dialogue (though providing only few clear examples such as anecdotes about volunteers offering French cook books to foreign teams during the World Junior Rowing Championships in Brive) as well as the inclusion of disabled persons. Besides social capital, all respondents mention sport participation (15, 9\%, see quotation 4), and although it may be surprising for nonparticipatory events, the absence of sport participation opportunities is perceived as a negative outcome for some respondents (quotation 5). Furthermore, beyond references to youth, women and senior participation, we found that several quotations relating to sport participation were also linked to human capital around a broader dimension, namely 'development of local clubs', as illustrated by the example of Orléans:

'Following our judo club, which is one of the largest French clubs, other clubs started to bid for events. Our fencing club had the Women World Fencing Cup, our gymnastic club hosted an international gala with the European Union of Gymnastics [...]. Setting big events is the better way for them to grow and to attract new members. It is also very challenging for their volunteers because they have to find financial partners, to promote the event [...]. And for example, following the gala they engaged a partnership with two retirement homes to provide soft gym lessons for elderlies' (Orléans).

These findings are further evidenced by the example of Angers, whose Director of sports explains that the hosting of the National Athletics Championships allowed the organizing club to develop expertise, which materialized through a convention in order to host two other editions within the next five years. Several volunteers will notably pass a certificate to become competition judges, and the city encourages its swimming club to follow this example. This provides some grounds - although based on few examples - for Taks' (2013) assumption that non-mega sport events may represent better opportunities for local community empowerment than mega events, notably because these events are directly 
organized by local clubs.

Well-being is also mentioned (6\%, see quotation 6), but here again few examples are provided, respondents rather referring to the semantic field of celebration with terms like 'enthusiasm', 'animation', 'festive atmosphere', 'colors', 'funny disguise' and pointing that events attract 'family audiences', 'parents and children', 'sport fans and non-sport fans'. This dimension also draws an important number of negative perceptions. Most of them relate to the various disturbances (hoon effect) that events can engender (quotation 9). Independently from these issues, the lack of organizers' commitment to generate well-being is perceived negatively by some respondents (quotation 8).

Another noticeable aspect relates to urban regeneration, while few works have evidenced this kind of benefits in non-mega events (at the exception of Taks et al., 2012). In our sample, four local governments provided examples of urban regeneration, two of them referring to the construction or upgrading of sport facilities (quotation 13), one on an extension of a museum dedicated to horses. The last example refers to the construction of an assembly platform for which the event is seen as an important catalyst as it constitutes a privileged place for talks between local and Chinese industrial partners.

Interestingly, we did not find consistent differences (in the number or nature of mentioned impacts) between one-off and recurrent events, except on collective identities. Indeed, regarding this dimension (3\%), only recurrent events are evoked, as some of them seem to constitute elements of the local cultural heritage (quotation 11). Furthermore, it seems that this status is a key asset for securing public funding and support despite their negative impacts, as illustrated by the example of Le Touquet, whose motocross event was almost cancelled because of its multiple negative impacts (noise, crowding, waste, uncivil behaviors), but was finally maintained due to the strong attachment of the majority of the local community. 
Table 2. Local governments' perceptions of non-mega sport events' social impacts.

\begin{tabular}{|c|c|c|c|c|c|c|}
\hline & \multicolumn{3}{|r|}{ Positive impacts } & \multicolumn{3}{|r|}{ Negative impacts } \\
\hline Content & $\begin{array}{c}\mathrm{Nb} \text { of } \\
\text { respondents }\end{array}$ & $\begin{array}{c}\mathrm{Nb} \text { of } \\
\text { quotations }\end{array}$ & Sample quotations & $\mid \begin{array}{c}\mathrm{Nb} \text { of } \\
\text { respondents }\end{array}$ & $\begin{array}{c}\mathrm{Nb} \text { of } \\
\text { quotations }\end{array}$ & Sample quotations \\
\hline $\begin{array}{l}\text { Social capital } \\
\text { Benefits for youth } \\
\text { Benefits for } \\
\text { disadvantaged } \\
\text { groups } \\
\text { Local citizenship } \\
\text { Neighborhood } \\
\text { connections } \\
\text { Inclusion of } \\
\text { disabled persons } \\
\text { Intercultural } \\
\text { dialogue }\end{array}$ & $\begin{array}{l}8 \\
5 \\
3 \\
3\end{array}$ & $\begin{array}{c}\mathbf{7 6}(\mathbf{2 8 , 9 \% * )} \\
24(9,1 \% *) \\
20(7,6 \% *) \\
11(4,2 \% *) \\
9(3,4 \% *) \\
7(2,7 \% *) \\
5(1,9 \% *)\end{array}$ & $\begin{array}{l}\text { (1) "[The event] allows inner-city youth to } \\
\text { come and see champions, and they have the } \\
\text { opportunity to meet them" (Tourcoing, benefits } \\
\text { for disadvantaged groups). } \\
\text { (2) "And each year a donation is made to a } \\
\text { local association called Blue Childhood, which } \\
\text { fights violence against children" (Ivry-sur- } \\
\text { Seine, local citizenship). }\end{array}$ & $\begin{array}{l}4 \\
0 \\
0 \\
1 \\
0\end{array}$ & $\begin{array}{c}1(4,2 \% *) \\
4(1,5 \% *) \\
6(2,3 \% *) \\
0(0 \% *) \\
0(0 \% *) \\
1(0,4 \% *) \\
0(0 \% *)\end{array}$ & $\begin{array}{c}\text { (3) "Organizers don't systematically think } \\
\text { about people that cannot afford the tickets, for } \\
\text { us that is of course a problem because these } \\
\text { events have to be democratized in some way" } \\
\text { (Dunkerque, benefits for disadvantaged } \\
\text { groups). }\end{array}$ \\
\hline $\begin{array}{l}\text { Sport participation } \\
\text { Youth participation } \\
\text { Development of } \\
\text { local clubs } \\
\text { Health benefits } \\
\text { Women } \\
\text { participation } \\
\text { Senior } \\
\text { participation }\end{array}$ & $\begin{array}{l}25 \\
10 \\
7 \\
6 \\
3 \\
2\end{array}$ & $\begin{array}{c}42(15,9 \% *) \\
16(6 \% *) \\
14(5,3 \% *) \\
7(2,7 \% *) \\
3(1,1 \% *) \\
2(0,8 \% *)\end{array}$ & $\begin{array}{l}\text { (4) "On the morning before the finals, children } \\
\text { are invited and have free swimming lessons } \\
\text { from federal educators" (Rennes, youth } \\
\text { participation). }\end{array}$ & $\begin{array}{l}7 \\
2 \\
1 \\
0 \\
1\end{array}$ & $\begin{array}{c}\mathbf{6}(\mathbf{2 , 3 \%}) \\
3(1,1 \% *) \\
1(0,4 \% *) \\
0(0 \% *) \\
1(0,4 \% *) \\
1(0,4 \% *)\end{array}$ & $\begin{array}{l}\text { (5) "There was no opportunity for children to } \\
\text { get bikes and ride some mounds, I know it has } \\
\text { been done elsewhere, it was a bit } \\
\text { disappointing" (Bordeaux, youth participation). }\end{array}$ \\
\hline
\end{tabular}




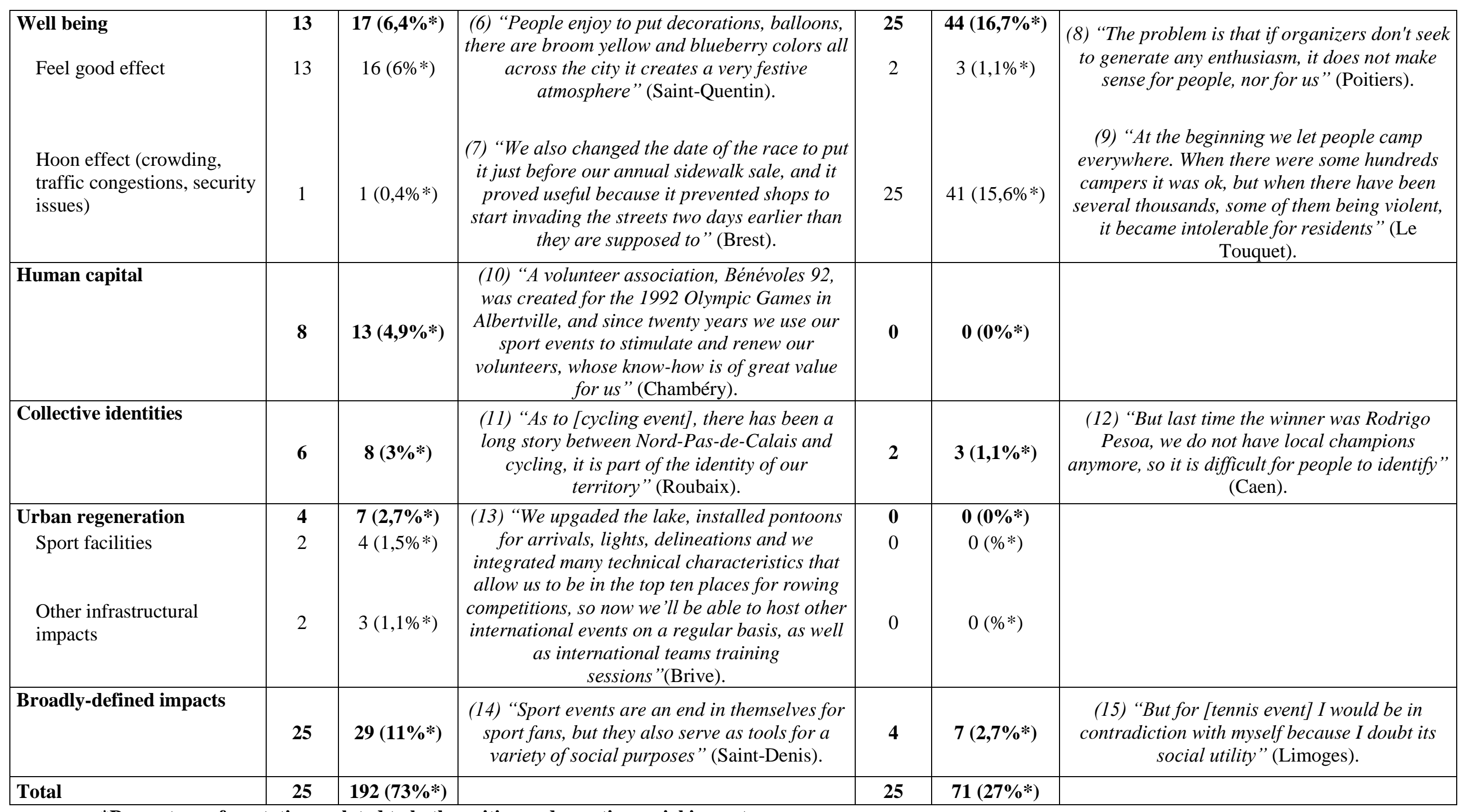

*Percentage of quotations related to both positive and negative social impacts. 
In view of the low scanning activity of local governments regarding positive impacts, their predominance in the perceptions of respondents may appear surprising. However, the analysis of the controllability of these impacts provides some interesting explanations to such results.

\section{Controllability as a path for action.}

Although local governments seem to point more positive than negative impacts, we found that they actually do not control most of the positive impacts they perceive (see Table 3). Firstly, nearly a half of the total positive impacts mentioned are only 'supposed impacts', namely impacts not supported with clear examples. They notably include an important number of quotations which evoke sport events' social leverage power albeit in a very vague manner (quotation 16). 
Table 3. Controllability of non-mega sport events' social impacts for local governments.

\begin{tabular}{|c|c|c|c|c|c|c|}
\hline \multirow[b]{2}{*}{ Content } & \multicolumn{3}{|r|}{ Positive impacts } & \multicolumn{3}{|r|}{ Negative impacts } \\
\hline & $\begin{array}{c}\mathrm{Nb} \text { of } \\
\text { respondents }\end{array}$ & $\begin{array}{c}\mathrm{Nb} \text { of } \\
\text { quotations }\end{array}$ & Sample quotations & $\begin{array}{c}\mathrm{Nb} \text { of } \\
\text { respondents }\end{array}$ & $\begin{array}{c}\mathrm{Nb} \text { of } \\
\text { quotations }\end{array}$ & Sample quotations \\
\hline $\begin{array}{l}\text { Supposed } \\
\text { impacts }\end{array}$ & 25 & $\begin{array}{c}93 \\
(48,4 \% *)\end{array}$ & $\begin{array}{l}\text { (16) "Sport has always been imbued with } \\
\text { social values. And sport events are a vector } \\
\text { of social cohesion, which is also part of the } \\
\text { current climate" (Saint-Quentin, broadly- } \\
\text { defined impact). }\end{array}$ & 7 & $7(9,9 \% * *)$ & $\begin{array}{l}\text { (17) "There are certainly people that are } \\
\text { bothered in some ways, but if they don't } \\
\text { express their complaints, we can't do } \\
\text { anything to help them" (Brive, hoon effect). }\end{array}$ \\
\hline $\begin{array}{l}\text { Observed } \\
\text { impacts }\end{array}$ & 25 & $\begin{array}{c}58 \\
(30,2 \% *)\end{array}$ & $\begin{array}{c}\text { (18) “[The organizers] also developed a } \\
\text { workshop where teenagers can learn how } \\
\text { to drive their moped safely" (Le Touquet, } \\
\text { benefits for youth). }\end{array}$ & 12 & $\begin{array}{c}12 \\
(16,9 \% * *)\end{array}$ & $\begin{array}{l}\text { (19) "Unfortunately we were not yet } \\
\text { equipped to accommodate more than fifteen } \\
\text { disabled persons, it has not been easy to get } \\
\text { this message across our clubs" } \\
\text { (Dunkerque, inclusion of disabled persons). }\end{array}$ \\
\hline $\begin{array}{l}\text { Controlled } \\
\text { impacts }\end{array}$ & 18 & $\begin{array}{c}41 \\
(21,4 \% *)\end{array}$ & $\begin{array}{c}\text { (20) "As the event was broadcasted on } \\
\text { cable TV, we also installed a giant screen } \\
\text { so that people who did not have a ticket } \\
\text { could watch it and have some fun" (Angers, } \\
\text { well-being). }\end{array}$ & 25 & $\begin{array}{c}52 \\
(73,2 \% * *)\end{array}$ & $\begin{array}{l}\text { (21) "We finally decided to move the event } \\
\text { near the Hippodrome in order to avoid any } \\
\text { congestion in the city center" (Bordeaux, } \\
\text { traffic congestion) }\end{array}$ \\
\hline Total impacts & 25 & $\begin{array}{c}192 \\
(100 \% *)\end{array}$ & & 25 & $\begin{array}{c}71 \\
(100 \% * *)\end{array}$ & \\
\hline
\end{tabular}

*Percentage of quotations related to positive impacts.

**Percentage of quotations related to negative impacts. 
This large number of supposed impacts tends to show that local officials, probably due to their lack of scanning activity, largely base their decisions on assumptions and do not consistently seek evidences of the social benefits events may produce.

Secondly, we found that another $30 \%$ of positive social impacts were 'observed impacts', namely impacts for which respondents provide clear examples, but which they did not control directly - most of them deriving from actions initiated by the organizers themselves (quotation 18). As a consequence, only $21 \%$ of the reported positive impacts were subjected to local governments' involvement (quotation 20).

Beyond scanning issues, a line of explanation for this poor level of local governments' involvement is the confidence some local officials express to organizers, to whom they simply entrust the management of positive impacts, as suggested by this statement:

We do not need to write down specific objectives [related to social impacts] in our partnership agreements, up to now organizers have always been quite proactive in this area' (Soorts-Hossegor).

Concerning negative impacts, our findings interestingly show a quite opposite trend. Indeed, 'supposed' negative impacts are few (9, $9 \%$ of the total negative impacts mentioned). They essentially reflect the fear that the event cause adverse effects which would not be identified (quotation 17). Similarly, 'observed' negative impacts are limited (16,9\%) and mostly include negative impacts that have been identified but which local governments, for some reason, could not prevent (quotation 19). Lastly, our results show that while respondents perceive less negative than positive impacts, they are proportionally more involved in the management of negative impacts $(73,2 \%$ of the reported negative impacts).

This apparent difference may have several levels of explanation. At a first level, it seems that negative impacts are subjected to a stronger scanning activity from local governments, which allow them to be better identified and controlled. Furthermore, the very nature of negative impacts may make them appear more controllable than positive impacts. Indeed, most 'controlled' negative impacts are tangible issues like noise or other disturbances to residents, whereas a large number of positive impacts refer to intangible and latent dimensions like social capital or collective identities - which may seem harder to control. Finally, from a broader perspective, negative impacts may be given a greater importance than positive impacts, meaning that the presence of the formers is deemed more problematic than the absence of the latters. This way, negative impacts would elicit a need to be controlled, while positive impacts would be interpreted as a mere bonus due to sheer coincidence. Such explanation is illustrated by the following quote:

'[...] even if some [local residents] will always be reluctant, will point that there are two decibels above the limit, etc... We do everything we can to meet their demands. But beyond that, maybe their youngsters will come and see the world champion, maybe the day after they will buy a skateboard and start 
practicing, and so maybe next time parents will be in a better mood' (Montpellier).

For these reasons, it seems that risk management imperatives take precedence over social leverage concerns.

\subsection{Action.}

In spite of this general gap between perceived and controlled impacts, local governments do supplement their hosting strategies with actions aiming at managing negative as well as, for some of them, positive impacts. We grouped these actions within four categories: organizer relationship management, direct management, community mobilization, and partnerships with local corporations (see Table 4). 
Table 4. Forms of local governments' involvement in the management of non-mega sport events' social impacts

\begin{tabular}{|c|c|c|c|c|c|c|}
\hline & \multicolumn{3}{|r|}{ Positive impacts } & \multicolumn{3}{|r|}{ Negative impacts } \\
\hline Content & $\begin{array}{c}\mathrm{Nb} \text { of } \\
\text { respondents }\end{array}$ & $\begin{array}{c}\mathrm{Nb} \text { of } \\
\text { quotations }\end{array}$ & Sample quotations & $\begin{array}{c}\mathrm{Nb} \text { of } \\
\text { respondents }\end{array}$ & $\begin{array}{c}\mathrm{Nb} \text { of } \\
\text { quotations }\end{array}$ & Sample quotations \\
\hline $\begin{array}{l}\text { Relationship } \\
\text { management }\end{array}$ & 8 & $\begin{array}{c}13 \\
(31,7 \% *)\end{array}$ & $\begin{array}{c}\text { (22) "In our partnership agreement we } \\
\text { mentioned that organizers must take actions } \\
\text { in favor of social integration" (Brive, } \\
\text { broadly-defined impact). }\end{array}$ & 17 & $\begin{array}{c}19 \\
(36,5 \% * *)\end{array}$ & $\begin{array}{c}\text { (23) "We have inserted a clause that limits } \\
\text { the number of decibels, notably when } \\
\text { organizers play music" (Montpellier, } \\
\text { noise). }\end{array}$ \\
\hline $\begin{array}{c}\text { Direct } \\
\text { management }\end{array}$ & 15 & $\begin{array}{c}17 \\
(41,5 \% *)\end{array}$ & $\begin{array}{l}\text { (24) “Here we have a 'democratization of } \\
\text { events' policy that consists in price } \\
\text { reduction upon presentation of documents } \\
\text { like job-seeker cards" (Lille, benefits for } \\
\text { disadvantaged groups). }\end{array}$ & 25 & $\begin{array}{c}32 \\
(61,6 \% * *)\end{array}$ & $\begin{array}{c}\text { (25) "Even if organizers have their own } \\
\text { security staff, we deploy policemen as it is } \\
\text { our mission to ensure security" (Brest, } \\
\text { security issues). }\end{array}$ \\
\hline $\begin{array}{l}\text { Community } \\
\text { mobilization }\end{array}$ & 4 & $9(22 \% *)$ & $\begin{array}{l}\text { (26) "Thanks to this project we managed to } \\
\text { bring together people that don't usually } \\
\text { encounter each other [...] they were all } \\
\text { gathered in front of [giant made of straw] } \\
\text { to cheer as the cyclists passed" (Roubaix, } \\
\text { neighborhood connections, well-being). }\end{array}$ & 1 & $1(1,9 \% * *)$ & $\begin{array}{c}\text { (27) “After the event we appeal to } \\
\text { associations and local clubs to help } \\
\text { cleaning the beach" (Le Touquet, waste } \\
\text { collection). }\end{array}$ \\
\hline $\begin{array}{l}\text { Partnerships } \\
\text { with local } \\
\text { corporations }\end{array}$ & 2 & $2(4,8 \% *)$ & $\begin{array}{c}\text { (28) "For the City it is a priority to ensure } \\
\text { that the jobs provided by [job agency } \\
\text { name] benefit our residents, so that they } \\
\text { draw a salary and enrich their job } \\
\text { experience" (Nice, benefits for } \\
\text { disadvantaged groups). }\end{array}$ & 0 & $0(0 \% * *)$ & \\
\hline $\begin{array}{c}\text { Total } \\
\text { managed } \\
\text { impacts }\end{array}$ & 18 & $\begin{array}{c}41 \\
(100 \% *)\end{array}$ & & 25 & $\begin{array}{c}52 \\
(100 \% * *)\end{array}$ & \\
\hline
\end{tabular}




\section{Organizer relationship management.}

A first way for local governments to enable positive and prevent negative impacts is to use their utilitarian power (Parent \& Deephouse, 2007), namely the fact that they hold important resources (public funding, access to sport facilities) on which organizers are dependent, to impose conditions in the partnership agreements. This utilitarian power seems to be relevant for non-mega events, as evidenced by several respondents that compared them with larger events like the Tour de France:

'We obviously do not have the same relationship with [organizers of the Fise Xperience Series] than with Amaury Sport Organization [ASO - organizers of the Tour de France], the balance of power is not the same. ASO is a huge machine, whether you accept their conditions or they go and see the next city' (Reims).

Even with respect to events that require a bid process, several respondents point that most of the time, right-holders rely on local clubs for the organization. Since those clubs have relationships with local governments on a regular basis, they are all the more receptive to the city's expectations. As a result, 17 interviewees have revised their general models of partnership agreements for sport events. However, nine only added criteria concerning negative impacts, such as noise reduction or site clearance (quotation 23). Eight integrated criteria related to positive impacts. Out of them, six require that organizers engage in social integration actions without more specifications, which puts a new emphasis on the lack of scanning, as social impacts are defined in a very broad way (quotation 22). The two others ask organizers to take part to existing social programs like 'Montpellier Mission Sport' which aims at providing opportunities for inner-city youth, or 'Vivre ensemble à Orléans - Sport et Handicap', dedicated to people with disabilities. While these programs allow for a better identification of the desired impacts (benefits for disadvantaged groups, inclusion of disabled persons), they also illustrate the prevalence of internal information in the scanning process, as these programs are part of the broader municipal sport policy and are not base on events' specific characteristics.

Furthermore, it seems that the sensemaking process leading to this form of relationship management has to take into account exogenous factors such as political compromises, as some events are considered too important, from an economic view-point, to risk tarnishing the relationship with organizers. This view is expressed by the following example:

'When I have meetings with the Mayor's team, they want to hear that we earned four euros for each euro invested in the event. I mean for this event the economic rationale prevails over everything else, clearly they do not want me to impose anything on organizers' (Poitiers).

\section{Direct management.}

Outside of the relationship with organizers, local governments also directly manage specific social impacts. This form of action also tends to concern more negative than positive impacts. A reason is that negative impacts such as crowding, traffic congestion and security 
issues, have always been in their area of competence (quotation 25). By contrast, addressing positive impacts through direct management seems less common. The most addressed impact is benefits for disadvantaged groups, as 14 local governments put in place a systematic lowpricing policy for unemployed people and free invitations to community centers, as found in Lille since 2009 through its 'democratization of events' policy' (quotation 24). Here again, such actions essentially derive from internal sources of scanning, as same policies are implemented for non-sport events like festivals or music concerts. But local governments' direct management can also aim at other impacts. For example, as the capacity of sport facilities is limited, some cities like Angers or Saint-Denis punctually install giant screens so that the whole community can gather and watch the event, thus facilitating neighborhood connections and well-being. Interestingly, such actions are partly based on external information integrated to the scanning process, as one respondent explains:

'Actually I had already seen it [the use of a giant screen] during a Champions League Match in Munich. The atmosphere was great, pretty much like in a stadium [...] So I wanted to try it [for the Six Nations Tournament]' (SaintDenis).

\section{Community mobilization.}

Another form of local governments' involvement consists of using the momentum of hosted events to mobilize various groups of the local community. Interestingly - although it concerns only five cities - this form of involvement is mainly directed towards positive impacts (in four cities out of five). What's more, several kinds of impacts are mentioned. For example, two cities use events to provide animation and education opportunities for children. The city of Metz, in collaboration with local schools, built an educative project related to their annual ATP 250 tournament, called 'Junior Journalists'. In the weeks preceding the event, pupils have the opportunity to discover sports journalism. A visit of a local newspaper is organized, during which journalists help them prepare a press conference. During the event, they are encouraged to ask questions to tennis players.

Another example is the city of Roubaix, which started the confection of a giant cyclist made of straw and plastic plugs for the Paris-Roubaix race. This project mobilized local residents, various associations, local farmers and even retirement homes, thus creating neighborhood connections as well as recreational activities, notably for seniors. This also increased well-being during the event, as participants joined together to celebrate their creation (quotation 26).

Hence, from a sensemaking perspective, community mobilization seems of a great interest for two reasons. Firstly, it involves a more accurate targeting of potential benefits for specific groups (neighborhood connections for nearby residents, animation and education opportunities for children, local citizenship opportunities for associations, recreational activities for seniors). This is due to the fact that these few local governments do not just assume local community's desired outcomes, but they enrich their scanning activity by encouraging various groups to define these outcomes themselves: 
'We increasingly exchanged with these schools, with teachers, and they had the idea of this project around journalism, because it fitted their program' (Metz).

Secondly, community mobilization implies a shift in the sensemaking process, by which members of the local community are not only perceived as the beneficiaries of social actions, but also as their very resources. In this regard, a last example is the city of Chambéry which, together with other cities in the Savoie area, has maintained strong links with a volunteer association created in 1992 for preparing the hosting of the Olympic Games in Albertville. With more than 30000 members at this period, this association has remained active and mobilizes volunteers for various large and small scale events, training new members and thus representing an invaluable source of human capital.

\section{Partnerships with local corporations.}

Several authors evoked the role of corporations, through their corporate social responsibility strategies, in providing social outcomes for sport events (Babiak \& Wolfe, 2006; Misener \& Mason, 2010). In our sample, we found that there was a noticeable lack of scanning from local governments about social actions led by local corporations during the hosted events. Indeed, most of them just assumed that local corporations may be involved in such actions, but were unable to provide illustrations, as those partnerships were engaged between corporations and the organizers.

However, two cities have engaged partnerships directly with corporations. The first example is the city of Nice, which hosts an annual ATP tennis tournament. One of the main sponsors of this tournament is a job agency, whose partnership includes the recruitment of workers for the organization of the event. As this event usually drew applicants from several surrounding cities as well as more remote regions, the city of Nice - which is the main financial partner of the event - viewed these jobs as a source of social and human capital, in the sense that they could benefit disadvantaged groups' quality of life and skills building (quotation 28).

Therefore, the city established a partnership with the job agency in order to reserve these job opportunities for its inhabitants, specifically those of low-income. The organizing committee acted as an intermediary, as both partners assisted preparatory meetings.

The other example is the partnership between the city of Le Havre and the title-sponsor of the Transat Jacques Vabre, a coffee company. As the respondent explains, the company had undertaken a repositioning of its image towards corporate social responsibility and sustainability. Hence, it was willing to enrich its partnership with environmental and social actions. This was integrated as a cue in the scanning process of this Director of sports, who therefore envisioned opportunities for the local community. From there, the city concluded a partnership with the company, and notably obtained from this latter the funding of a kit for school teachers providing educative material about Brazil - the destination of the race - thus providing benefits for children. 
This sensemaking process is interesting in that the information integrated to the scanning process include local corporations' objectives in terms of corporate social responsibility, which can represent valuable resources for social outcomes for the local community.

\section{Discussion and conclusion.}

As authors recently begun to examine how sporting events can be leveraged to generate social benefits, there is a consensus that they are generally subject to weak attempts on these matters (Beesley \& Chalip 2011; Chalip, 2006; Kellett \& Chalip, 2008). In this paper, we explored non-mega events social impacts through the perspectives of one of their main stakeholders, namely local governments, drawing on the postulate that they have (or should have) an immediate interest in those impacts given their role of community representatives. Based on strategic sensemaking, which describes how organizations make sense of potential outcomes and construct plausible paths to achieve these outcomes, the main findings of this study is to identify factors linked to strategic sensemaking (see Figure 1) that may foster or inhibit effective leveraging strategies as advocated by Kellett et al. (2008). 
Figure 1. Local Governments' Sensemaking Process of Non-Mega Sport Events' Social Impacts

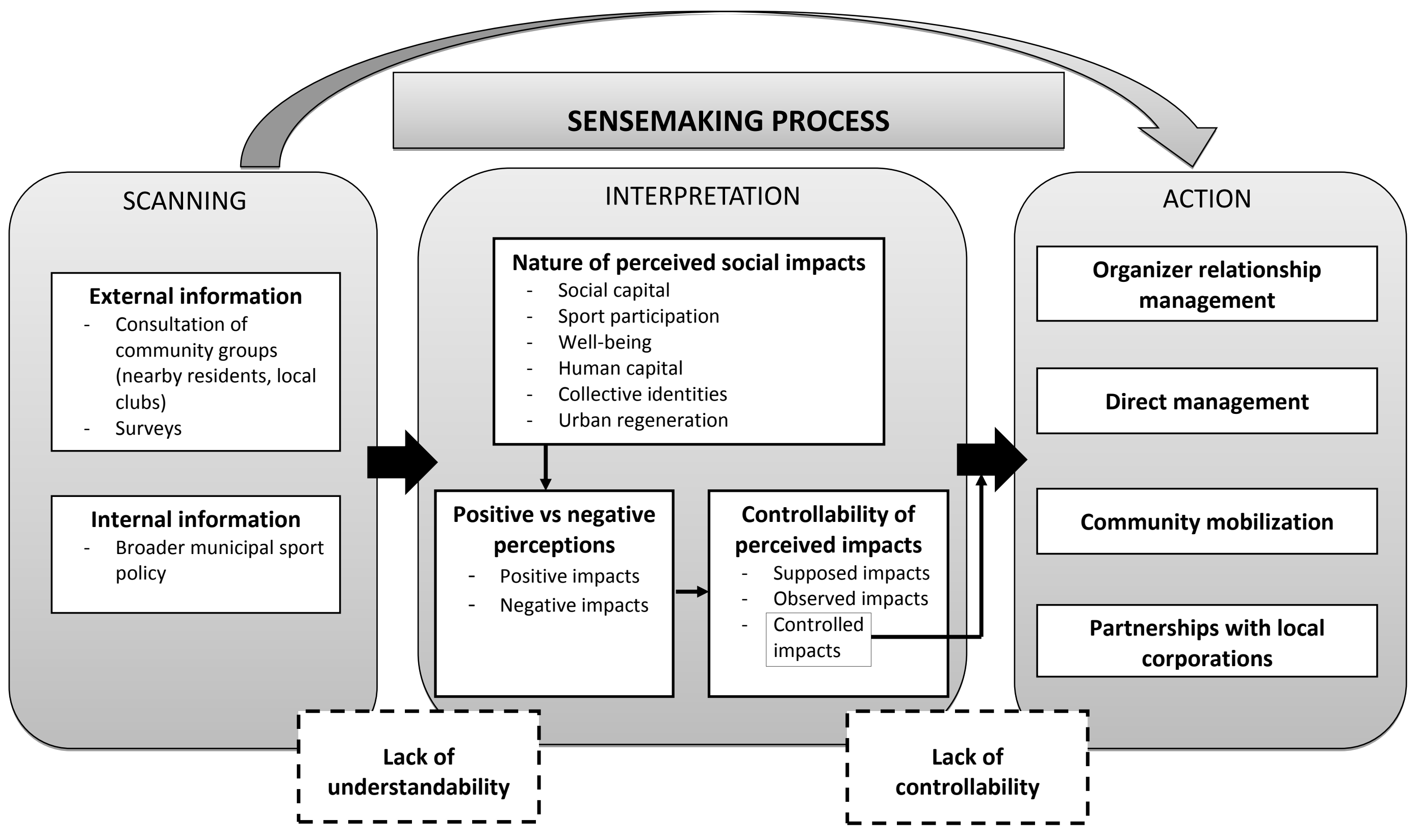


The first factor relates to a lack of understanding of what kind of benefits events may bring to the local community. Local governments are ideally positioned to envision possible social outcomes for their community. However, their scanning activity seems too limited to enable them to identify social leveraging opportunities, because most of them relate on few external information, which furthermore is essentially linked to negative impacts. Hence, a main consequence of such scanning process relates to the missed opportunities that can be observed. For example, while there are four tennis tournaments sharing common characteristics in our sample, they are not equally leveraged from one city to another: albeit Limoges has hosted Fed Cup matches on a quite regular basis (2009, 2013, 2014), there are neither educative projects for children as found in Metz, nor job opportunities for disadvantaged people like the ones provided by Nice. Besides, while some local governments do identify social issues that can be addressed during sport events, these are generally broader issues coming from internal sources of information, namely the broader municipal sport policy. In this sense, sport events are only viewed as opportunities in a broad fashion, since the same issues are addressed in all sport events, regardless of their specific features. This may notably explain why this study surprisingly identifies very few differences between one-off and recurrent sport events. Indeed, due to the lack of integration of events' specificities in their scanning process, most local governments take standard actions such as systematic low-pricing or inclusion of disabled persons. These actions paradoxically create a form of recurrence in the impacts generated, thus reducing the differences between both types of events.

To address this lack of scanning, there is a need for a comprehensive social and community impact assessment, as some scholars already argue in the case of mega sport events (Horne \& Manzenreiter, 2006; Kidd, 1992). Although the stakes for non-mega events are not of a similar magnitude, local governments would gain from collecting more external information. They could look into the development of relevant indicators (local sport participation, women participation, volunteer rates). However, as they generally do not possess personnel specifically dedicated to collect and analyze empirical information, they could turn to local universities which can provide such capabilities. More importantly, a greater variety of community groups should be integrated into their scanning process both as sources and recipients of information, since long established literature points that citizens' involvement in public policies is crucial for their satisfaction (Bente, 2010). At last, local governments should also gather information on the results of their social policies during events. Indeed, a lack of evaluative information seems critical as these policies may be deemed not worthy of sustaining simply because they have not been clearly shown to be effective.

Beyond the understandability of impacts, a second factor relates to their controllability. Indeed, the interpretation phase points that a large number of sport events' positive impacts are observed but not controlled by local governments, meaning that the paths leading to these impacts remain poorly developed. Rather, local governments tend to offload this task to sport events' organizers. However, literature consistently shows that organizers are often overwhelmed by the primary concern of delivering high quality events and are therefore unable to adequately leverage them, especially when it comes to non-economic outcomes (O’Brien \& Chalip, 2008; Taks, Misener, Chalip \& Green, 2013). In contrast, the stronger controllability of negative impacts may be explained by political contingencies. Since citizens' dissatisfaction has a greater effect than their satisfaction on their appraisal of public 
policies (Holian, 2011), democratic governments tend to be very responsive to complaints. This general trend may be applicable to sport events' policies, concentrating local officials' attention on negative impacts.

Still, several ways of increasing the controllability of positive impacts can be suggested. However, they require that the sensemaking process not only identify potential beneficiaries, but also potential contributors to these impacts. A first way is to foster self-sustaining and human capital building for local clubs, which could then be the first contributors. On this matter, cities can play a key role in helping clubs to not simply follow right-holders' requirements, but to develop genuine bottomup strategies aiming at gaining radiance and reaching out to various groups, as shown by the example of Orléans and Angers. Cities can also facilitate knowledge transfer between clubs, notably by stimulating the creation of inter-club volunteer associations - such as the 'Bénévole 92' association mentioned by Chambéry - that provide clubs with organizational capabilities and experience.

Interestingly, other contributors of sport events' social outcomes may be their beneficiaries themselves. Indeed, our results reveal that strategies of 'community mobilization' have emerged in some cities. These strategies are built on community empowerment, through the activation of various community networks, primarily schools and local associations, to launch event-related social or educative activities prior and during the events. Hence these groups usefully take over local governments' sensemaking process by providing links between interpretation (identification of a potential outcome) and action (development of paths to achieve this outcome).

Lastly, albeit on the basis of the few examples provided in our sample, we argue that local corporations can be important contributors to sport events' social impacts. Indeed, literature shows that corporate sponsors have a growing interest in expressing their social responsibility during sport events (Dowling, Robinson \& Washington, 2013). What's more, public authorities are important stakeholders of local corporations, whose social responsibility actions can be aimed at avoiding regulation or taxation. Hence, by integrating these corporations to the sensemaking process and focusing their attention on targeted social issues that can be addressed during sport events, local governments can provide them opportunities to express their CSR, as illustrated by the examples of Nice and Le Havre. Such strategies may also help reducing the tension expressed by some respondents between social and economic outcomes. Presumably, enticing corporations to supplement their sponsorship deals with social actions may increase their overall investment.

It has to be noticed that our findings may be influenced by some specificities of the French context. Firstly, public intervention in sports, and more particularly the use of sports as a tool for social policies, is an historical pattern of the French sport model (Lafranchi, 2000). In this regard, in other countries non-mega events' social impacts may be more addressed by private initiatives such as Grass Roots Sports, a corporation based in UK which provides sport courses and events for children (aimed at fostering positive attitudes) on a for-profit basis. Furthermore, some social issues may not be addressed in events set up in France. For example, there are no French policies directly referring to ethnic minorities such as Black, Asian or minority ethnic origin (BAME) policies in $\mathrm{UK}^{2}$. In a similar

\footnotetext{
${ }^{2}$ The UK government notably secured jobs for BAME persons during the 2012 Olympic Games in London.
} 
fashion, while Amsterdam hosted Gay Games in 2002, there have not been such initiatives in France to our knowledge.

A main limitation of this study is that we intended to provide a global vision of non-mega sport events' social impacts. This approach does not allow for a detailed understanding of how specific events can bring distinct outcomes in particular settings. For this reason, we propose several suggestions for future research. A first avenue lies in the comparison of non-mega sport events characteristics regarding social outcomes. Indeed, non-mega events include one-off and recurrent, spectator and participatory, mono and multi-sports, men, women and mixed, within and outside sport facilities events.

Hence, further research should provide, through case studies, deeper comparisons between the various categories of non-mega events in order to identify patterns linking social outcomes to events' characteristics. Similarly, research should focus on the inherent characteristics of cities hosting these events. Indeed, most research has addressed the use of large scale sport events by large cities as part of a more structural transition from industrial to leisure economy (Misener \& Mason, 2006; Whitson \& Macintosh, 1996). Small and medium-sized cities, which can hardly achieve the same global exposure, may develop totally different sport events agendas, even regarding major (albeit non-mega) events. Some of them may, for example, seek to open up to the world while maintaining a strong collective identity, as exampled by Basque cities hosting the World Championships of Basque Pelota (Callède, 1993). Lastly, another important limitation of our study is that we analyzed the sensemaking process of only one category of sport events' stakeholders. Since the social leveraging of sport events involves interactions between various actors, future research could move on to explore other stakeholders' perspectives and strategies.

\section{References}

Angus-Leppan, T., Metcalf, L. A., \& Benn, S. H. (2010). Leadership styles and CSR practice: An examination of sensemaking, institutional drivers and CSR leadership. Journal of Business Ethics, 93(2), 189-213. doi: 10.1007/s10551-009-0221-y

Babiak, K., \& Wolfe, R. (2006). More than just a game? Corporate social responsibility and Super Bowl XL. Sport Marketing Quarterly, 15(4), 214-222.

Balduck, A., Maes, M., \& Buelens, M. (2011). The Social Impact of the Tour de France: Comparisons of Residents' Pre- and Post-event Perceptions. European Sport Management Quarterly, 11(2), 91-113. doi: 10.1080/16184742.2011.559134

Bandara, W. (2006). Using Nvivo as a research management tool: A case narrative. Quality and Impact of Qualitative Research, 6.

Basu, K., \& Palazzo, G. (2008). Corporate Social Responsibility: A Process Model of Sensemaking. Academy of Management Review, 33(1), 122-136. Doi:10.5465/AMR.2008.27745504 
Bente, F-M. (2010). Implications of citizen participation in local public administration upon citizens' satisfaction. Annals Of The University Of Oradea, Economic Science Series, 19(2), 1074-1080.

Beesley, L. G., \& Chalip, L. (2011). Seeking (and not seeking) to leverage mega-sport events in nonhost destinations: The case of Shanghai and the Beijing Olympics. Journal Of Sport \& Tourism, 16(4), 323-344. doi:10.1080/14775085.2011.635016

Briedenhann, J. (2011). Economic and Tourism Expectations of the 2010 FIFA World Cup - A Resident Perspective. Journal Of Sport \& Tourism, 16(1), 5-32. doi:10.1080/14775085.2011.568085

Brown, A. \& Massey, J. (2001). Literature review: The impact of major sporting events. London: UK Sport.

Buffington, D. (2012). Us and Them: U.S. Ambivalence Toward the World Cup and American Nationalism. Journal Of Sport \& Social Issues, 36(2), 135-154.

Callede, J. P. (1993). Basque Pelota in the European space... Towards a sociological use of the notions of sporting evolution and diffusion. International Review For The Sociology Of Sport, 28(2), 223-243.

Carey, M., Mason, D. S., \& Misener, L. (2011). Social Responsibility and the Competitive Bid Process for Major Sporting Events. Journal of Sport and Social Issues, 35(3), 246-263. doi: $10.1177 / 0193723511416985$

Cashman, R. (2006). The Bitter-Sweet Awakening: The Legacy of the Sydney 2000 Olympic Games, Walla Walla Press, Sydney, Australia.

Chalip, L. (2006). Towards social leverage of sport events. Journal of Sport \& Tourism, 11(2), 109127. doi:10.1080/14775080601155126

Coleman, J. S. (1994). Foundation of social theory. Cambridge, MA: Belknap Press.

Dowling, M., Robinson, L., \& Washington, M. (2013). Taking advantage of the London 2012 Olympic Games: corporate social responsibility through sport partnerships. European Sport Management Quarterly, 13(3), 269-292. doi: 10.1080/16184742.2013.774039

Dutton, J.E., Ashford, S.J., O’Neill, R.M., \& Lawrence, K.A. (2001). Moves that matter: Issue selling and organizational change. Academy of Management Journal, 44(4), 716-736. doi: $10.2307 / 3069412$

Dutton, J. E, \& Duncan, R.B. (1987). The creation of momentum for change through the process of strategic issue diagnosis. Strategic Management Journal, 8(3), 279-295.

Dutton, J. E., \& Webster, J. (1988). Patterns of interest around issues: The role of uncertainty and feasibility. Academy of Management Journal, 31(3), 663-675. doi: 10.2307/256464

Dutton. J. E., \& Jackson, S.E. (1987). Categorizing strategic issues: Links to organizational actions. Academy of Management Review, 12(1), 76-90. doi: 10.5465/AMR.1987.4306483 
Fischer, A., Hatch, J., \& Paix, B. (1986). Road accidents and the Grand Prix. In: J.P.A. Burns, J.H. Hatch, \& T.J. Mules (Eds). The Adelaide Grand Prix: The impact of a special event, The Centre for South Australian Economic Studies (pp151-168), Adelaide.

Frawley, S., \& Cush, A. (2011). Major sport events and participation legacy: the case of the 2003 Rugby World Cup. Managing Leisure, 16(1), 65-76.

Fredline, E., \& Faulkner, B. (2002). Residents' reactions to the staging of major motorsport events within their communities: A cluster analysis. Event Management, 7(2), 103-114.

George, R., \& Swart, K. (2012). International tourists' perceptions of crime-risk and their future travel intentions during the 2010 FIFA World Cup ${ }^{\mathrm{TM}}$ in South Africa. Journal of Sport \& Tourism, 17(3), 201-223. doi: 10.1080/14775085.2012.734060

Gioia, D.A. (1986). Symbols, scripts, and sensemaking: Creating meaning in the organizational experience. In H.P. Sims, Jr., \& D.A. Gioia (Eds.), The thinking organization (pp. 49-74). San Francisco: Jossey-Bass.

Gioia, D. A. \& Chittipeddi, K. (1991). Sensemaking and sensegiving in strategic change initiation. Strategic Management Journal 12(6), 433-448.

Gioia, D. and A. Mehra: 1996, Review of Karl Weick's Sensemaking in Organizations. Academy of Management Review, 21(4), 1226-1230.

Girginov, V. \& Hall, L. (2008). A sustainable sports legacy: Creating a link between the London Olympics and sports participation. The International Journal of the History of Sport, 25(4), 2091-2116.

Gratton, C. \& Taylor, P. (2000). Economics of sport and recreation. London: Spon.

Hall, C. M. (1992). Adventure, sport and health tourism. In B. Weiler \& C. M. Hall (Eds.), Special interest tourism (pp. 141-158). London: Belhaven.

Hall, C.M. (1992). Hallmark Tourist Events: Impacts, Management, and Planning. London: Bellhaven.

Hillenbrand, C., Money, K., \& Pavelin, S. (2012). Stakeholder-defined Corporate Responsibility for a pre-credit crunch financial service company. Journal of Business Ethics, 105(3), 337-356. doi: 10.1007/s10551-011-0969-8

Hiller, H. H. (2000). Mega-events, urban boosterism and growth strategies: An analy-sis of the objectives and legitimations of the Cape Town 2004 Olympic bid. International Journal of Urban and Regional Research, 24(2), 439-458. doi:10.1111/1468-2427.00256

Holian, M. J. (2011). Homeownership, dissatisfaction and voting. Journal Of Housing Economics, 20(4), 267-275. doi:10.1016/j.jhe.2011.08.001

Horne, J. \& Manzenreiter W. (2006). Sports mega-events: Social scientific analyses of a global phenomenon. Oxford: Blackwell Publishing. 
Jennings, A. (2000). The Great Olympic Swindle. London: Simon \& Schuster Ltd.

Jones, M., \& Stokes, T. (2003). The Commonwealth Games and urban regeneration: An investigation into training initiatives and partnerships and their effects on disadvantaged groups in East Manchester. Managing Leisure, 8(4), 198-212.

Kavetsos, G., \& Szymanski, S. (2009). From the Olympics to the grassroots: What will London 2012 mean for sport funding and participation in Britain?. Public Policy Research, 16(3), 192-196. doi:10.1111/j.1744-540X.2009.00580.x

Kellett, P., Hede, A., \& Chalip, L. (2008). Social policy for sport events: Leveraging (relationships with) teams from other Nations for community benefit. European Sport Management Quarterly, 8(2), 101-121. doi: 10.1080/16184740802024344

Kidd, B. (1992). The Toronto Olympic commitment: Towards a social contract for the Olympic Games. Olympika: The International Journal of Olympic Studies, 1, 154-167.

Lafranchi, P. (2000). Entre initiative privée et question nationale. Génèse et évolution des politiques sportives en Europe (Grande-Bretagne, Allemagne, France, Italie). Politix, 13(50), 29-48.

Lee, S., Cornwell, T., \& Babiak, K. (2013). Developing an Instrument to Measure the Social Impact of Sport: Social Capital, Collective Identities, Health Literacy, Weil-Being and Human Capital. Journal of Sport Management, 27(1), 24-42.

Leopkey, B., \& Parent, M. (2009). Risk management issues in large-scale sporting events: A stakeholder perspective. European Sport Management Quarterly. 9(2), 187-208. doi: $10.1080 / 16184740802571443$

Maitlis, S. (2005). The social processes of organizational sensemaking. Academy of Management Journal, 48(1), 21-49. doi:10.5465/AMJ.2005.15993111

Maitlis, S., \& Sonenshein, S. (2010). Sensemaking in Crisis and Change: Inspiration and Insights From Weick (1988). Journal of Management Studies, 47(3), 551-580. doi: 10.1111/j.14676486.2010.00908.x

McCabe, S. (2006). The making of community identity through historic festive practice: the case of Ashbourne Royal Shrovetide Football. In D. Picard \& M. Robinson (Eds.), Festivals, tourism and social change (pp. 99-118). Clevedon, UK: Channel View Publications.

Misener, L., \& Mason, D. S. (2006). Creating community networks: Can sporting events offer meaningful sources of social capital? Managing Leisure, 11(1), 39-56.

Misener, L., \& Mason, D. S. (2008). Urban regimes and the sporting events agenda: A cross national comparison of civic development strategies. Journal of Sport Management, 22(5), 603-627.

Misener, L., \& Mason, D. S. (2009). Fostering community development through sport-ing events strategies: An examination of urban regime perceptions. Journal of Sport Management, 23(6), 770-794. 
Misener, L., \& Mason, D. S. (2010). Towards a community centered approach to corporate community involvement in the sporting events agenda. Journal of Management \& Organization 16(4), 495514.

Nicholson, M. \& Hoye, R. (2008). Sport and Social Capital. London: Elsevier ButterworthHeinemann.

O'Brien, D. (2007). Points of leverage: Maximizing host community benefit from a re-gional surfing festival. European Sport Management Quarterly, 7(2), 141-165. doi: $10.1080 / 16184740701353315$

O'Brien, D., and Chalip, L. (2008). Sport events and strategic leveraging: Pushing towards the triple bottom line. In A. Woodside and D. Martin (Eds), Tourism Management: Analysis, Behaviour, and Strategy (pp. 318-338). Oxfordshire, UK: CABI Publishing.

Ohmann, S., Jones, I. \& Wilkes, K. (2006). The perceived social impacts of the 2006 Football World Cup on Munich residents. Journal of Sport \& Tourism, 11(2), 129-152.

Owen, K. (2002). The sydney 2000 Olympic and urban entrepreneurialism: local variations in urban governance. Australian Geographical Studies, 40(3), 323-336.

Parent, M. M. \& Deephouse, D. L. (2007). A case study of stakeholder identification and prioritization by managers. Journal of Business Ethics, 75(1): 1-23. doi: 10.1007/s10551-007-9533-y

Pegoraro, A., O'Reilly , N., and Levallet, N. (2009). Gender-based sponsorship of grassroots events as an agent of corporate social responsibility: The case of a national women's triathlon series. Journal of Sponsorship, 2(2), 140-151.

Preuss, H. (2004). The economics of staging the Olympics: A comparison of the Games 1972-2008. Cheltenham: Edward Elgar.

Preuss, H. (2007). FIFA World Cup 2006 and its legacy on tourism. In R. Conrady \& M. Buck (Eds.), Trends and issues in global tourism (pp. 83-102). Berlin/Heidelberg: Springer.

Preuss, H., \& Solberg, H.A. (2006). Attracting Major Sporting Events: The role of Local Residents. European Sport Management Quarterly, 6(4),391-411. doi: 10.1080/16184740601154524

Ritchie, B. J. R. (1984). Assessing the impact of hallmark events: Conceptual and research issues. Journal of Travel Research, 23, 2-11. doi:10.1177/004728758402300101

Roche, W. M. (1994). Mega-events \& urban policy. Annals of Tourism Research, 21, 1-19.

Ruhanen, L., \& Whitford, M. (2011). Indigenous sporting events: More than just a game. International Journal of Event Management Research, 6(1), 33-51.

Smith, A. (2009). Theorising the relationship between major sport events and social sustainability. Journal of Sport Tourism, 14(2/3), 109-120. 
Spilling, O. R. (1996). The entrepreneurial system: On entrepreneurship in the context of a megaevent. Journal of Business Research, 36, 91-103. doi: 10.1016/0148-2963(95)00166-2

Taks, M., Kesenne, S., Chalip, L., Green, B. C. \& Martyn, S. (2011). Economic impact study versus cost-benefit analysis: an empirical example of a medium sized international sporting event. International Journal of Sport Finances, 6(3), 187-203.

Taks, M., Chalip, L., Green, B. C. \& Misener, L. (2012). Exploring the impact of sport events on sustainable sport participation outcomes in local communities. In Sport between business and civil society (Abstract book of the $20^{\text {th }}$ EASM conference; 144). Aalborg: EASM/UCN.

Taks., M. (2013). Social sustainability of non-mega sport events in a global world. European Journal for Sport and Society, 10(2), 121-141.

Taks, M., Misener, L., Chalip, L., \& Green, B.C. (2013). Leveraging sport events for participation. Canadian Journal for Social Research, 3(1), 12-23.

Thomas, J. B., Clark, S. M. \& Gioia, D. A. (1993) Strategic sensemaking and organisational performance: linkages among scanning, interpretation, action, and outcomes Academy of Management Journal 36(2), 239-270. doi: 10.2307/256522

Thomas, J. B., \& McDaniel .R.R., Jr. (1990). Interpreting strategic issues: Effects of strategy and the information-processing structure of top management teams. Academy of Management Journal, 33(2), 286-306. doi: 10.2307/256326

Walker, M., Heere, B., Gibson, H., Thapa, B., Geldenhuys, S. \& Coetzee, W. (2012). The power of sport to unite a nation: The social value of the 2010 South African World Cup. In Book of abstracts $\left(27^{\text {th }}\right.$ Annual conference of the North American Society for Sport Management 2012) (510-511). Seattle, WA: NASSM.

Weed, M., Coren, E. and Fiore, J. (2009). A Systematic Review of the Evidence Base for Developing a Physical Activity and Health Legacy from the London 2012 Olympic and Paralympic Games. Canterbury, Centre for Sport, Physical Education and Activity Research, Canterbury Christ Church University.

Weick, K. E. (1979). The Social Psychology of Organizing 2nd ed. New York, NY: McGraw-Hill.

Weick, K. E. (1995) Sensemaking in organisations. Thousand Oakes, CA: Sage.

Whitson, D., \& Horne, J. (2006). Underestimated costs and overestimated benefits? Comparing the outcomes of sports mega-events in Canada and Japan. In J. Horne \& W. Manzenreiter (Eds.), Sport mega-events: Social scientific perspectives of a global phenomenon (pp. 73-89). Oxford: Blackwell Publishing.

Whitson, D.J. and Macintosh, D. (1996). The global circus: International sport, tourism, and the marketing of cities. Journal of Sport and Social Issues, 20(3), 278-97. 
Wicker, P., Hallman, K., Breuer, C. \& Feiler, S. (2012). The value of Olympic success and the intangible effects of sport events - a contingent valuation approach in Germany. European Sport Management Quarterly, 12(4), 337-355. doi: 10.1080/16184742.2012.693117

Xing, X., \& Chalip, L. (2006). Effects of Hosting a Sport Event on Destination Brand: A Test of Cobranding and Match-up Models. Sport Management Review, 9(1), 49-78.

Zhuang, J. \& Girginov, V. (2012). Volunteer selection and social, human and political capital: a case study of the Beijing 2008 Olympic Games. Managing Leisure, 17(2/3), 239-256. doi: $10.1080 / 13606719.2012 .674397$ 